\title{
The Death Journey of a Hopi Indian: A Case Study
}

\author{
J. Timothy Green, Ph.D. \\ Laguna Hills, CA
}

ABSTRACT: I present the case study of the "death journey" or near-death experience (NDE) of Don Talayesva, a Hopi Indian, whose experience occurred between 1900 and 1910. I compare and contrast his experience with 11 accounts of Native American NDEs reported by Jenny Wade (2003), as well as with modern day NDEs. Talayesva's NDE took him to the Hopi land of the dead, where he witnessed the brutal fate of witches and Two-Hearts before returning to physical existence. Although his and many other NDEs from indigenous populations appear to adhere to cultural expectations and beliefs, that has not been the case with modern day NDEs collected from Anglo-Saxon cultures.

KEY WORDS: near-death experience; Hopi; Native Americans; shamanism.

Jenny Wade (2003) was the first to tackle the difficult area of an overview of Native American accounts of near-death experiences (NDEs). Although not meant to be a complete record of all Native American NDEs, her paper presented 11 interesting and representative accounts.

Wade outlined many of the problems associated with this type of research and noted that it is difficult if not impossible to bring today's standards for field studies to this area of study. Her accounts spanned four centuries, six cultures, and most of the North American continent. Some accounts were firsthand, some secondhand. Others were translated, possibly quite poorly, and some were gathered by

J. Timothy Green, Ph.D., is a clinical psychologist in private practice in Laguna Hills, CA. The writer would like to thank Jenny Wade, Ph.D., for her help in reading and making valuable comments during the writing of this article. Requests for reprints should be addressed to Dr. Green at 25255 Cabot Road, Suite 210, Laguna Hills, CA 92653; e-mail: jospeverde@aol.com. 
colonists whose cultural biases may have further distorted the meanings of the accounts. Many accounts came from oral traditions that had been handed down from generation to generation. Native Americans language does not always convey the same linguistic constructs and nuances that other cultures do. For instance, they may talk about different states of consciousness, such as dreaming, waking consciousness, and shamanic journeys without making arbitrary distinctions between these episodes. To them, they are all simply experiences. Wade also cited a number of studies from other indigenous cultures, something that $I$ forgo in this article so as to focus specifically on Native American accounts.

I will add one more case study to Wade's accounts of Native American NDEs, one that, while only a single account, has none of the limitations Wade discussed. I will describe in full the "death journey" of a Hopi Indian named Don Talayesva. Talayesva's account is firsthand, by a man who had a good grasp of English, the language in which he wrote. He kept a journal for many years, and it was from this that a book was eventually published by a friend of Talayesva, the anthropologist Leonard Simmons. Simmons had so much respect for both Talayesva and the Hopi Nation that he eventually became Talayesva's adopted brother and lived with him and his family for a period of time.

The following account comes from the autobiography entitled Sun Chief: The Autobiography of a Hopi Indian, first published in 1942. Talayesva was born in 1890 and lived most of his life in Oraibi, a settlement in Arizona approximately 10 miles east of the Grand Canyon. At age 10, he was sent to live at a boarding school run by Christian missionaries in Riverside, California. During this period, sometime between 1900 and 1910, he learned to read and write quite well. While in Riverside, Talayesva developed pneumonia, which became progressively worse over a four-week period. He reported that, while hospitalized and not expected to live, he had the following experience:

Then I saw a human being standing by my bed in Katcina costume. He was well dressed in a dancing kilt and a sash, was barefoot, and wore long black hair hanging down his back. He had a soft prayer feather (nakwakwosi) in his hair and carried a blue one in his left hand - blue being the color which signifies the west and the home of the dead. He wore beads and looked wonderful as he watched me. When the nurses brought food he said, "My son, you had better eat. Your time is up. You shall travel to the place where the dead live and 
see what it is like." I saw the door swing slowly back and forth on its hinges and stop just a little open. A cold numbness crept up my body; my eyes closed, and I knew I was dying.

The strange human being said, "Now, my boy, you are to learn a lesson. I have been guarding you all your life, but you have been careless. You shall travel to the House of the Dead and learn that life is important. The path is already made for you. You better hurry and perhaps you will get back before they bury your body. I am your Guardian Spirit (dumalaitaka). I will wait here and watch over your body, but I shall also protect you on your journey." (Talayesva, 1942, p. 121)

Talayesva's experience began in some ways much like that of many modern NDEs, with the experiencer knowing that he was dying and being accompanied by a spiritual being. In the passage below, he also described the lack of any pain and implied leaving his physical body and the presence of a tunnel, all commonly reported components of modern NDEs:

The pain disappeared and I felt well and strong. I arose from my bed and started to walk, when something lifted me and pushed me along through the air, causing me to move through the door, down the hall, and out upon the campus in broad daylight. I was swept along northeastward by a gust of wind, like flying, and soon reached the San Bernardino Mountains. There I climbed a corn-meal path about halfway up a mountain and came upon a hole like a tunnel, dimly lighted. I heard a voice on the right saying, "Don't be afraid, walk right in." Stepping in through a fog and past the little lights, I moved along swiftly, finally coming out upon a flat mesa, and discovered that I was walking near the old water holes out on the ledge at Oraibi! Very much surprised, I thought, "I will go home and get some good Hopi food.” (Talayesva, 1942, pp. 121-22)

The most obvious difference between Talayesva's account and those of many present day NDEs was the almost complete absence of a description of a bright light of any kind. He did report a tunnel, "dimly lighted," and also "little lights," but these were hardly consistent with the overwhelmingly bright light that many modern NDErs report. Throughout his experience, Talayesva never mentioned anything resembling the brilliant light many NDErs have reported over the past 30 years; nor were they reported in any of Wade's accounts.

On the other hand, the following aspect of the experience was entirely consistent with many NDEs during which the person found himself at home, or with relatives, or other loved ones: 
As I entered the door, I saw my mother sitting on the floor combing my father's hair. They just stared at the door for a moment and then turned back to their interests. They didn't say a word, causing me to wonder sadly. I walked about the room for a minute and then sat down on a sheep pelt by the stove to think. I said to myself, "Well, perhaps my grandfather will come and give me food." After about an hour of silence, my grandfather did come in, stared at me for a moment, and said nothing; but he sat down opposite me and dropped his head as though worried. Then I thought to myself, "They don't care for me. I had better go and leave them alone." When I arose to leave they didn't even look up or say good-by.

I walked out by the dry basin near the Oraibi Rock. There was a little stone walk on the rim of the dam. A large lizard ran along the ground and into the wall. As I drew near I saw peeping out from the rocks an ugly, naked woman with drawn face and dry lips. She looked tired, half-starved, and very thirsty. It was my old grandmother, Bakabi, my mother's mother's sister. Since she was still living, I didn't know how her spirit could be on its way to Skeleton House; but I think my Guardian Angel placed her there to teach me a lesson and to show me that she was a Two-Heart. She said, "My grandson, will you please give me a drink?" "No, I have no water," I replied. "Well, please spit in my mouth to quench my thirst?" she pleaded. I said, "No, I have nothing for you. Are you the one I saw as a lizard?" "Yes, my father is a lizard and I have two hearts." "Then I will have nothing to do with you, for you killed our sister!" I said. "I am one of those who are killing your people," she answered, "but I am not the one who killed you. From here to the House of the Dead you will see people like me who can take only one step a year over a path of sorrow. Please let me go along with you. You have only one heart and will arrive safely." "Never mind," I said, and hurried along, for I had no time to monkey with a witch. (Talayesva, 1942, pp. 122-23)

Witches, whom the Hopi also refer to as "Two-Hearts," are believed to be people who often kill relatives in order to prolong their own lives, as well as causing many other types of mischief. Talayesva's understanding of witches or Two-Hearts was that they were a very unfortunate but powerful people, members of every race and nation, organized into a worldwide society in which they spoke a common language. Talayesva believed that Hopi Two-Hearts were leaders of this terrible society, that they held their underworld convention at Red Cliff Mesa northeast of Oraibi, and that Two-Hearts in Oraibi were probably the worst of the lot. They were thought to be mean, fussy, easily offended, and forever up to mischief (Talayesva, 1942, p. 120)

This component of seeing in the spirit world a relative or other person who is still alive is very much at odds with present day NDEs, as well as with the accounts that Wade presented. It is very unusual in 
a modern day NDE for the individual to report seeing a relative or friend unless that person was, in fact, deceased.

As Talayesva's account continued, he encountered other TwoHearts, ascended a series of steps, heard a bell, and came upon another guide who told him which of two roads he was to take:

I moved along quickly, touching the ground only in spots until I came to the west point of the mesa. Along this way I saw many faces of TwoHearts who called out to for food and drink; but I had no time for them. When I reached the foot of Mount Beautiful, the Judgment Seat, I looked up and saw nice regular steps about twelve feet wide and twelve feet high, of a red color, and reaching like a mighty stairway to the highest point. I started to climb but seemed to float up on air, just touching my feet lightly on the top step. There a bell rang from the west side so clearly that I heard echoes out among the mesa walls.

As the ringing grew louder, I looked and saw a man climbing up the mountain from the west, dressed in a white buckskin, wearing a horn, and holding a spear and a bell. It was a Kwanitaka, a member of the Kwan or Warrior society, who watches the kivas during prayers and guards the village to keep out strangers and let in the dead during the Wowochim ceremonies. He came up to me but did not shake hands, because he was a spirit god and doing police duty directing good people over the smooth highway and bad people over the rough road to the House of the Dead. He said, "My boy, you are just in time, hurry! Look to the west and you will see two roads. You take the broad one, the narrow one is crooked and full of rocks, thorns and thistles; those who take it have a hard journey. I have prepared this broad road for you. Now hurry and you will find someone to guide you."

I looked to the left and saw a wide road sprinkled with corn meal and pollen. On the right was a narrow path about a foot wide and very rough. Strewn along the side were Hopi clothes that had been dropped by Two-Heart women who had received them from men with whom they had slept. I saw naked, suffering people struggling along the path with heavy burdens and other handicaps such as thorny cactus plants fastened to their bodies in tender places. Snakes raised their heads along the edge of the path, sticking out their tongues in a threatening manner. When they saw me looking at them they dropped their heads; but I knew they could bite anyone that they did not like.

I chose the broad road to the left and went along swiftly, almost flying, until I came to a large mesa, which I shot up like an arrow and landed on the top. There I saw on my left summer birds singing and flowers in full bloom. Moving rapidly, I passed along the edge of Cole Canyon with its steep white walls which I had seen before on my way to Moenkopi. In the distance were twelve queer-looking striped animals chasing one another. As I drew nearer I saw that they were 
clowns (tcuka) who had painted their bodies with black and white stripes and were joking and teasing one another. The leader - who was one of the Eagle Clan which is linked to my Sun Clan - said, "My nephew, we have been expecting you. It is late and you must hurry. We think you will return, so we will wait here for you. Your Guardian Spirit is protecting you; but you must hurry. Your Guardian Spirit is protecting you; but you must hurry back to your body. You may live a long time yet if you get back." (Talayesva, 1942, pp. 123-24)

In the following passage, Talayesva passed a test by correctly deciding to have his hair washed with white suds, and came to the end of his journey, where he witnessed the brutal fate of Two-Hearts:

Somewhat frightened, I sped along to the left, reached the top of the steep mesa, and sort of floated down. Before me were the two trails passing westward through the gap of the mountains. On the right was the rough narrow path, with the cactus and the coiled snakes, and filled with miserable Two-Hearts making very slow and painful progress. On the left was the fine, smooth highway with no person in sight, since everyone had sped along so swiftly. I took it, passed many ruins and deserted houses, reached the mountain, entered a narrow valley, and crossed through a gap to the other side. Soon I came to a great canyon where my journey seemed to end; and I stood there on the rim wondering what to do. Peering deep into the canyon, I saw something shiny winding its way like a silver thread on the bottom; and I thought that it must be the Little Colorado River. On the walls across the canyon were the houses of our ancestors with smoke rising from the chimneys and people sitting out on the roofs.

Within a short time I heard a bell on the west side at the bottom of the canyon and another one somewhat behind me. The same Kwanitaka who had directed me on Mount Beautiful came rushing up the cliff carrying a blanket and dressed in a cloak and buckskin moccasins as white as snow. Another Kwanitaka came rapidly from the rear, ringing his bell. The first one said, "We have been expecting you all morning. This partner and I have raced here for you. I won and you are mine. You have been careless and don't believe in the Skeleton House where your people go when they die. You think that people, dogs, burros, and other animals just die and that's all there is to it. Come with us. We shall teach you a lesson on life." I followed the first Kwanitaka to the southwest and was trailed by a second who kept off evil spirits. We came to a house where we saw a Kwanitaka in red buckskin moccasin making red yucca suds in a big earthen pot. Near by was another Kwanitaka from the west in white moccasins making vapor to rise like a cloud. Then one of them said, "Now we are ready, take your choice. From which pot will you be washed?" I chose the white suds. "All right, you are lucky," said the Kwanitaka. "It means that you may journey back along the Hopi trail and return to life." I knelt down so that he could wash my hair and rinse it with 
fresh water. Finally, he said, "Get up and come along. We must hurry because time is going fast."

The Kwanitakas led me southwest toward the smoke rising in the distance. As we drew near I saw a great crowd of people watching a fire which came out of the ground. On the very edge of the flaming pit stood four naked people, each of them in front of another individual who wore clothing. On the north and south sides stood a naked man in front of a clothed woman, on the east and west sides a naked woman in front of a clothed man. I could see these people as plain as day, even their private parts, but I did not know a single one of them. They had been traveling for a long, long time at a rate of one step a year, and had just reached this place. I noticed on the ground paths leading from four directions to the hole. Near by I saw another Kwanitaka tending the fire in a deeply tunneled pit like that in which sweet corn is baked.

"Look closely," said a Kwanitaka. "Those in front are Two-Hearts. They killed the people standing behind them and now it is their turn to suffer. The crowds of people have come from the House of the Dead to see the Two-Hearts get their punishment. Look!" Then he yelled out, "Ready, push!" The woman on the north pushed her Two-Heart into the pit and I could see the flames lap him up, sending out rolls of black smoke. Then the man on the west pushed over his naked woman, and the woman on the south shoved in her man, causing great volumes of smoke to rise out of the pit. Finally, the man on the east pushed his girl and the work was done. No Two-Heart said a word; it seemed they had no feelings. The Kwanitaka said to the people, "Now go back where you belong."

"Now, my boy," said the Kwanitaka to me, "come and look into the pit." I stepped up close to the rim and saw an empty hole with a network of two-inch cracks broken into the walls through which flames of fire were leaping. In the center at the bottom were four black beetles crawling about, two carrying the other two on their backs. The Kwanitaka asked me, "What do you see?" "Beetles," I replied. "That's the end of these Two-Hearts," said he, and the fate of all their kind." They will stay there as beetles forever, except to make occasional visits to Oraibi and move about the village doing mischief on hazy days."

The Kwanitakas then took me back over the course that we had traveled until we came to the steep ledge where the road had ended. I had stood there before, looking across the canyon to the opposite wall where people sat on their housetops. Now the canyon was full of smoke, and when we peered down I saw a gruesome creature in the shape of a man climbing the cliff. He was taking long strides with his shining black legs and big feet; an old tattered rag of a blanket was flying from his shoulder as he approached swiftly with a club in his hand. It was big, bloody-headed Masau'u, the god of Death, coming to catch me. One of the Kwanitakas pushed me and cried, "Flee for your life and don't look back, for if Masau'u catches you, he will make you a 
prisoner in the House of the Dead!" I turned and ran eastward, while they pushed me along with their wands or spears so that I rose about six inches from the ground and flew faster than I had ever traveled before.

When I reached Cole Canyon the clowns were waiting for me, standing in a straight line facing west with their arms about each other, as children do in playing London Bridge. As I approached them at full speed, they cried, "Jump, Masau'u is gaining." I jumped and landed on the chest of the leader knocking him down. They all laughed and yelled, seeming not to mind for clowns are always happy. They said, "You just reached here in time, now you belong to us, turn around and look." I looked west and saw Masau'u going back, looking over his shoulder as he ran. Then the leader of the clowns said, "Now, my nephew, you have learned your lesson. Be careful, wise, and good, and treat everybody fairly. If you do, they will respect you and will help you out of trouble. Your Guardian Spirit has punished you so that you may see and understand. Lots of people love you. We are your uncles and will see that no harm comes to you. You have a long time to live yet. Go back to the hospital and to your bed. You will see an ugly person lying there; but don't be afraid. Put your arms around his neck and warm yourself, and you'll soon come to life. But hurry, before the people put your body in a coffin and nail down the lid, for then it will be too late."

I turned and ran quickly, circling the mountains through the tunnel and over the foothills to the hospital. I entered quickly and saw my Guardian Spirit and a nurse at the bedside. He greeted me kindly and said, "Well, you are lucky, and just in time. Slip quickly under the cover at the foot, move up alongside your body, put your arms around its neck, and be still." My body was cold and little more than bones, but I obeyed the command and lay there clinging to its neck. Soon I became warm, opened my eyes, and looked up to the ceiling and at the door transom. Nurses were about the bed, and the head nurse was holding my hand. I heard her say, "The pulse beats." The head nurse said," Sonny, you passed away last night, but did not cool off quite like a dead person. Your heart kept beating slowly and your pulse moved a little, so we did not bury you." (Talayesva, 1942, pp. 123-27)

Later the same day that Talayesva returned from his death journey, his Guardian Angel made another bedside appearance to give him the following warning:

"Well, my boy, you were careless, but you learned a lesson. Now if you don't obey me I shall punish you again, but for only four trials - then I will let you die. I love you, and that is why I watch over you. Eat and regain your strength. Some day you will be an important man in ceremonies. Then make a paho for me before all others, for I am your Guardian Spirit that directs and protects you. Many people never see 
their Guide, but I have shown myself to you to teach you this lesson. Now I shall leave you. Be good, be wise, think before you act, and you will live a long time. But I shall hold you lightly, as between two fingers, and if you disobey me I will drop you. Good-by and good luck." He made one step and disappeared. (Talayesva, 1942, p. 128)

We know that Talayesva's death journey was not unique in Hopi culture, because following his experience he told a chief about it. This chief was able to verify that others had told of similar accounts: "Chief Tewaquaptewa visited me in the hospital, and when I told him about my death journey he said it was true, for those were the same things that the old people said they saw when they visited the House of the Dead" (Talayesva, 1942, p. 129). Talayesva also mentioned that his mother experienced a death journey, although he did not describe an account of her experience.

Talayesva became involved in the Katcina dancing just as his grandfather had prophecied. He described Katcina dancing as among "the greatest pleasures of his life" (Talayesva, 1942, p. 21). Finally, Talayesva's experience did have a significant impact on him. At the time of the experience he had been attending a Christian school and had begun to give up to old ways of the Hopi people. In looking back on the experience many years later, he wrote: "My death experience had taught me that I had a Hopi Spirit Guide whom I must follow if I wished to live. [Following the experience] I wanted to become a real Hopi again, to sing the good old Katcina songs" (Talayesva, 1942, p. 134). Elsewhere he wrote:

And, of course, I could never forget how the snakes dropped their heads when they saw me on the death journey and how my Guardian Spirit restored me to life and promised to protect me. All these things were proof to me that the ancestral spirits approved of my conduct and wanted me to stay on the Hopis Sun Trail. (Talayesva, 1942, p. 207)

\section{Conclusions}

In comparing and contrasting Wade's accounts with that of Talayesva, as well as modern day NDEs, all of the Native American accounts shared some components in common with NDEs that have been documented in the last three decades. However, there were also many differences between the 12 Native American accounts and modern day NDEs. Especially in Talayesva's experience, there was a 
great deal of distress. This is not commonly reported in Anglo-Saxon populations, although distressing NDEs have been documented (Greyson and Bush, 1992). There were also a number of cultural themes in Talayesva's experience, such as seeing Katcina dancers, witches, clowns, and Masau'u, all of which were aspects of Hopi cultural and belief. In contrast, most of the studies of modern NDEs in Anglo-Saxon cultures have shown no personal, social, cultural, or other demographic influences (Grey, 1985; Ring, 1980; Sabom, 1982; Sutherland, 1992).

The experience of seeing witches was unique to Talayesva's journey, as was seeing a person who was still alive in physical reality. None of Wade's accounts contained anything similar, nor do modern day NDEs. None of Wade's accounts described a Being of Light, seeing a light, going into a light, or an intelligent light, and this is consistent with Talayesva's experience. Neither Talayesva's account nor any of Wade's accounts contained a life review.

Six of Wade's accounts included journeys along a spirit road, as did Talayesva's. Three of her accounts included being led by a guide, as was Talayesva. Two of Wade's included interacting with the living, as did Talayesva.

Four of Wade's accounts involved meeting a challenge. Although somewhat different from the challenges Wade's account described, Talayesva did meet a type of a challenge by having his hair cleaned with white soap suds.

Three features, each found in five of Wade's accounts, were either questionable or absent in Talayesva's journey: light in the spirit world, reaching paradise, and finding death beatific.

Being told to return to life occurred in four of Wade's accounts and also occurred in Talayesva's. Returning unintentionally occurred in two of Wade's accounts, but not in Talayesva's. Receiving a commission occurred in four of Wade's accounts and also in Talayesva's, when he was told to live a good life and participate in the Katcina dancing. Finally, creating a commission occurred in three of Wade's accounts and also in Talayesva's.

Very little can be extrapolated with any confidence from these 12 accounts from Native American populations. As noted above, in some ways they are similar, while in others ways they are quite different both from each other and from modern day NDEs gathered from Anglo-Saxon cultures.

Carol Zaleski, who has studied accounts of NDEs in medieval and modern times wrote: 
What both critics and researchers failed to notice was the striking evidence for the cultural shaping of near-death experience. They were unaware that what we call "near-death experience" today is nothing new. ... [P]eople who return from death, bringing back eyewitness testimony about the other world, can be found in nearly every religious tradition; and although they have many similar features, such reports invariably portray this experience in ways that conform to cultural expectations. (Zaleski, 1995, p. 392)

The evidence presented here suggests that she is partially correct. On the one hand, most modern day NDEs gathered from Anglo-Saxon populations do not conform to our present day cultural expectations, while on the other hand the NDEs of many Native Americans from the past did conform to theirs.

\section{References}

Grey, M. (1985). Return from death: An exploration of the near-death experience. London, England: Arkana.

Greyson, B., and Bush, N. E. (1992). Distressing near-death experiences. Psychiatry, 55, 95-110.

Ring, R. (1980). Life at death: A scientific investigation of the near-death experience. New York, NY: Coward, McCann and Geoghegan.

Sabom, M. (1982). Recollections at death: A medical investigation. New York, NY: Harper and Row.

Sutherland, C. (1992). Reborn in the light: Life after near-death experiences. Sydney, Australia: Bantam.

Talayesva, D. (1942). Sun Chief: The autobiography of a Hopi Indian. New Haven, CT: Yale University Press.

Wade, J. (2003). In a sacred manner we died: Native American near-death experiences. Journal of Near-Death Studies, 23, 83-115.

Zaleski, C. (1995). Death and near-death today. In J. J. Collins and M. Fishbane (eds.), Death, ecstasy, and other worldly journeys (pp. 383-407). Albany, NY: State University of New York Press. 